\title{
Barriers to Effective Integration of Interactive Technology Learning Tools in Science Instruction
}

\author{
Annalene Grace E. Co', Kathleen Grace C. Magno', Fhrizz S. De Jesus ${ }^{2}$ \\ ${ }^{1}$ College of Teacher Education, Quirino State University, Diffun, Philippines \\ ${ }^{2}$ College of Management and Business Technology, Nueva Ecija University of Science and Technology, Palayan, Philippines \\ Email: annalenegrace.co@qsu.edu.ph, kathleengrace.magno@qsu.edu.ph,fhrizzdejesus01@gmail.com
}

How to cite this paper: Co, A.G.E., Magno, K.G.C. and De Jesus, F.S. (2021) Barriers to Effective Integration of Interactive Technology Learning Tools in Science Instruction. Open Access Library Journal, 8: e7724. https://doi.org/10.4236/oalib.1107724

Received: July 3, 2021

Accepted: July 31, 2021

Published: August 3, 2021

Copyright $\odot 2021$ by author(s) and Open Access Library Inc.

This work is licensed under the Creative Commons Attribution International License (CC BY 4.0).

http://creativecommons.org/licenses/by/4.0/

(c) (i) Open Access

\begin{abstract}
Information and communication technology has been accepted as a powerful tool that transforms education. The emergence of new and innovative uses of technology provides new approaches to science instruction. This descriptive study was conducted among the sixty-two faculty teaching science-related courses in the university. It aimed to determine the level of usage of interactive technology learning tools among the respondents and the barriers they encountered in using the tools. The result of the study revealed that the respondents use interactive technology learning tools in their science courses. The result showed a significant difference between respondents' usage of interactive learning tools with age and number of years in teaching science courses while not significant with gender. The level of usage was ranked from often used to never been used by most of the respondents. No significant relationship was noted between respondents' level of usage of the tools and barriers in using them. With the result of the barriers encountered by the respondents in using the interactive technology learning tools as to technical aspect, training, and support, and their views toward ICT usage, an ICT development plan was proposed to enhance the skills and knowledge in using interactive technology learning tools for the faculty to improve instruction.
\end{abstract}

\section{Subject Areas}

Information \& Communication Technology, Education, Science, Social Science

\section{Keywords}

Barriers, Usage, Interactive Technology Learning Tools, Information \& Communication Technology, Faculty 


\section{Introduction}

Individuals nowadays live in an age where technological advancement becomes inevitable. Due to the emergence of Artificial Intelligence (AI) and other Fourth Industrial Revolution innovations, teachers will remain indispensable in the quest for quality education [1]. The Secretary further emphasized that expectations for learning outcomes are no longer confined to reading, writing, and counting. In this line, the expectations for learning outcomes are no longer confined to reading, writing, and counting. Learners should now be able to read, grasp, analyze, process, and integrate information from a variety of sources, whether digital or printed because there are so many different types and sources of information available to them. This is the thing that 21 st-century abilities are about. It isn't sufficient for students to have the authority of ideas and topics [2]. They likewise need to have advanced proficiency and have what it takes for critical thinking and basic reasoning.

Information Communication Technologies (ICT) at present are influencing every aspect of human life [3]. ICT is playing noticeable roles in workplaces, business, education, and entertainment, and other industries. Today's students might not be learning the same way as how teachers taught students in the past generation [4]. To comprehend their reality, we should drench ourselves in the technology world. We should accept the new advanced reality. On the off chance that we can't relate, if we don't get it, we will not have the option to make schools applicable to the current and future requirements of the advanced age. The need to adapt to the new mode of learning for today's generation is continuously a big challenge for teachers of this millennial generation. There can be endless employments of PCs and innovations, however, if instructors themselves can't carry it into the study hall and make it work, at that point it comes up short [5].

Information Communication Technology assumes a significant part in human exercises in ordinary living to adapt constantly to the interest of the climate. On the off chance that the vision of science schooling is to bring a financial turn of events, the job of ICT in science training can't be overemphasized [6]. The world over, it is, for the most part, concurred that improvement must be important if and when it is science and innovation-driven.

The government has invested vast amounts of money to enhance schools with technology and provide them with Internet access to encourage teachers to use these new approaches. Public school teachers play an important role in our society, especially for the students [7]. However, the teachers still need to consider the technology for teaching and learning purposes.

It is with this context that this study was conducted to determine the respondents' level of usage of interactive technology learning tools including the barriers they encountered in using it in science instruction and how these have bearing on science teachers' performance so that a proposed ICT Development plan will be developed to enhance their skills in using ICT in teaching science. 
Specifically, it sought to 1) Determine the profile of the respondents as to age, gender and number of years in teaching science; 2) Determine the interactive technology learning tools used by respondents in teaching science; 3) Determine the respondents' level of usage of interactive technology learning tools in teaching science; 4) Determine if there is a significant difference between the respondents' level of usage of interactive technology learning tools when grouped according to their profile variables; 5) Determine the barriers encountered by the respondents in using interactive technology learning tools in teaching science; 6) Determine if there is a significant relationship between respondents' level of usage of interactive technology learning tool when grouped according to the barriers such as technical aspects, lack of training and support, and views toward ICT usage; 7) Propose an ICT development plan to increase the level of competence of science instructors in using interactive technology learning tools for instruction.

Hypothesis testing was used in this study. It was carried out in order to assess the evidence for the plausibility of the hypothesis based on the available data. Hypothesis testing is an act in statistics whereby an analyst tests an assumption regarding a population parameter [3]. Following hypotheses were tested in the study:

1. There is a significant difference between the respondents' level of usage of interactive technology learning tools when grouped according to their profile variables as to age, gender, and the number of years teaching science courses.

2. There is a significant relationship between respondents' level of usage of interactive technology learning tools when grouped according to the barriers such as technical aspects, lack of training and support, and views toward ICT usage.

\subsection{Literature Review}

The existing science tutoring reform requires science educators to integrate advancement and solicitation-based schooling into science direction, which is the most likely substitute for the science and growth of the twenty-first century. As a result, the Philippine government and private sectors have begun projects to equip schools with computer hardware and programming, web hosting, and teacher training. Other ICT activity programs incorporate Intel Teach to the Future Program, Mobile IT homerooms, and the Development of Computer-based instructional modules. These require a change in outlook from instructing about innovation to educating with innovation. Choy, Suan, and Chee study referenced that "what is energizing isn't simply more innovation yet that there are more kinds of innovation which instructor can single out from, in light of their educational inclinations" [8].

Utilizing intuitive innovation learning instruments in the homeroom isn't just about computerized gadgets in class. It can likewise identify with whatever encourages connection among instructor and understudy [9]. Being carefully proficient is more than getting "disengaged innovative abilities", as per the NMC 
Horizon Report: 2017 Higher Education Edition. Or maybe, it's tied in with "producing a more profound comprehension of the computerized climate, empowering natural variation to new settings and co-making of substance with others." Here, the whiteboard is practically terminated, while innovation has never been of more significance in the study hall. Making introductions, figuring out how to separate dependable from temperamental sources on the web, and keeping up legitimate online behavior is for the most part indispensable abilities that understudies can acquire in the study classroom is making introductions.

The following key finding was discovered in a new composing review on the impact of automated development on teaching and learning coordinated in England: There is convincing evidence that cutting-edge equipment, gadgets, and resources can be feasibly used to increase the speed and significance of learning in science and math for fundamental and assistant age understudies. There is trademark confirmation that the identical can be said for specific pieces of schooling, especially making and comprehension. Electronic advances appear to be legitimate means to improve central capability and numeracy capacities, especially in fundamental settings.

Students have progressed from attending a one-room school to getting the whole world at their fingertips in their homeroom [11]. [12] in the like manner contemplated that: using electronic resources outfitted understudies with greater freedom for dynamic learning in the homeroom; progressed gadgets and resources gave a more prominent opportunity to dynamic learning outside the investigation lobby, similarly as giving self-composed spaces, for instance, destinations and social events, and permission to games with a learning advantage; progressed resources outfitted understudies with opportunities to pick the learning resources; the resources gave safer spaces to formative assessment and analysis.

The most popular digital educational tools are Edmodo, Socrative, Project, Thinglink, TED-Ed, K-12, ClassDojo, eduClipper, Strongbird, Animoto, and Kahoot [13]. [14] 95\% or nearly all teachers are using technology nowadays. Video streaming beats out all others, some 60 percent of teachers use video streaming services, such as YouTube, in the classroom. That's followed by productivity and presentation tools like Microsoft Office and Google G Suite for Education at 54 percent. The social media category is teachers' least favorite type of tool, with just 13 percent of teachers reporting they use social media in the classroom.

In an article "Utilizing Technology as a learning apparatus, not simply the cool new thing" - the up and coming age of students will meet and outperform the Net Generation's assumptions for instructive principles [15]. Those guidelines may be met if staff and managers today build up the foundation of learning innovation in the study hall. Utilizing PowerPoint in the auditorium, yet seeing how innovation can be utilized to contact a great many people successfully. It will require incredible exertion on the two sides-understudies and workforce 
the same-to learn and utilize innovation adequately. However, the advantages will be justified even despite the exertion. GenZ (age Z) has been so submerged in innovation in each part of their lives that they presently don't consider it to be an extraordinary wonder, but instead as an ordinary, fundamental piece of life [15].

In the Republic of Ireland, as somewhere else, the utilization of online innovations has become an undeniably significant test in scholarly staff advancement. Be that as it may, without sufficient preparation and a consciousness of how to successfully actualize these apparatuses, the adequacy of these devices can get weakened and may even turn out to be counter-gainful [16]. When apparatuses become accessible, teachers should get sufficient preparing, to guarantee that they can accomplish successful utilization of these devices [16].

Information and Communication Technology gadgets and ICT-based exercises when viably implanted in science instructing can encourage more prominent learning in the science class [17]. It can connect with understudies and open up new roads of information availability. Nonetheless, equilibrium should be shown up between utilizing PC reproductions, showings, PowerPoint introductions, virtual tests, genuine active, reasonable exercises, and conventional communitarian bunch work. In any case, rather than the benefits of utilizing innovation in the homeroom, a few boundaries upset instructors from utilizing innovation. The ten reasons educators can battle to utilize innovation in the study hall are as follows: 1) Presented innovation isn't constantly liked; 2) Varying gadget abilities and guidelines; 3 ) It's simple for understudies to be diverted; 4) Innovation can influence exercise time and stream; 5) Instructors need a more expert turn of events; 6) Not every person has innovation at home; 7) Educators need to ensure understudies; 8) Not all instructors 'have confidence' in utilizing innovation; 9) Absence of satisfactory ICT backing, foundation, or time; 10) Pressures among understudies and instructors [18]. To add, the accompanying obstructions to the combination of ICT in Mathematics educating and learning incorporate educators' negative mentality, ability, and certainty, absence of time for mix. These hindrances are not gendered one-sided as uncovered by the examination [19].

Risk judgments are one of the convictions that are accountable for educators' defense from instructive innovations [20]. According to the study, hazard insight is characterized as an individual's assessment tool of the possible outcome occurring coupled with an assessment of how concerned they will be about the negative consequences of that occurrence.

Glazer, Hannafin, Polly, and Rid; Hammonds, Reynold \& Ingram, introduced the main four boundaries which remember educators' absence of certainty for their innovation abilities, tension over innovation competency, a dread of obliviousness before their understudies, and not understanding innovation as a tool [21].

Flipped study halls as an innovation in learning introduced obstructions in 
executing the said instructive innovation [22]. Flipped study hall instructing has become a critical pattern in schooling lately, yet there stay huge difficulties in convincing a few instructors to receive this novel technique. Flipped study hall gives an approach to change the customary example of learning and educating, with the workforce posting their class addresses online for understudies to see so they can utilize class time for active application, critical thinking, and evaluation. All in all, what was once homework becomes school work and what was once schoolwork becomes school work-consequently 'flipped'. The flipped study hall approach isn't just about doing schoolwork in class and conveying address material carefully to understudies outside of class. It is, indeed, an educational technique that means to stress learning over content conveyance by enhancing learning and showing exercises [23] while in the study hall, the learning and instructing centers around higher types of psychological work (applying, breaking down, assessing, and making in Bloom's updated scientific classification), and the lower levels (recollecting and understanding) are introduced before class through recorded talks and video.

There were ten seen impediments to the determination of ICT in schools [24]. The 10 assertions were isolated into three gatherings, as follows: The main gathering included four proclamations identified with the absence of ICT uphold, the subsequent gathering included three explanations identified with the absence of ICT foundation, and the third gathering included three things identified with the absence of inspiration and self-conviction. The ten distinguished obstructions were the accompanying: 1) Absence of subsidizing; 2) Absence of ICT joining; 3) Low availability; 4) Force interference; 5) Insufficient upkeep of equipment and programming; 6) Absence of gifted faculty; 7) Poor ICT foundation; 8) Absence of certainty; 9) Absence of inspiration; 10) Low attention to ICT benefits. Discoveries from this paper gave profound experiences into the variables that are upsetting the utilization of ICT in a more extensive scope of instructing and learning conditions. It is suggested that the administration and school board ought to know about the meaning of ICT in learning and educating and ought to conquer the obstructions that upset ICT utilization among instructors and understudies.

All instructive areas are required to be aware of the prospects and meaning of ICT in building up understudy's figuring out how to beat the hindrances which forestall innovation use in schools with the goal that understudies can profit viably from PC use. In corresponding with in-administration instructor preparing, specialized, monetary, and authoritative help is required for schools. Inside the more extensive region of ICT, there is an overall acknowledgment of the requirement for a proficient turn of events and backing to coordinate ICT productively and viably [25]. Instructors' apparent boundaries can be additionally investigated with bigger and more different examples. Moreover, this examination could be advanced by utilizing a blended strategy (e.g., subjective and quantitative ways to deal with) to acquire a superior comprehension of the circumstance. 
At the point when educators react to shut overview things, just the issues addressed can be recognized. While open-finished inquiries may uncover, for instance, how some recently announced obstructions have changed and may help in understanding the significance of hindrances while coordinating ICT in learning and instructing.

Three barriers in the integration of innovation in schools were additionally recognized as follows: instructor level boundaries, school-level obstructions, and framework level boundaries. At the instructor level obstructions, incorporate absence of certainty, absence of ICT fitness, educators' mentality, absence of preparing, restricted admittance, absence of specialized help, and non-view of advantages. The subsequent boundary distinguished as school-level boundaries incorporates the inadequate number of PCs, protection from change, progressed planning of PC lab, absence of help from the administration, non-accessibility of educating learning material, and nonattendance of ICT mainstreaming into schools. Also, the last distinguished hindrance is the framework level boundaries which incorporate an arrangement of assessment and assessment, and educational program load [26]. Accessibility of assets, time accessible for utilizing innovation, and educators' ability were discovered to be significant obstructions to utilizing PC innovation in the homeroom. Hence, organization, strategies can resolve the issue and increment the use of assets.

Although the Philippine government has started a few projects and tasks for the utilization of ICT in instruction, genuine usage in everyday learning is as yet restricted, instructors' dread of innovation prevents the ideal utilization of ICT-related abilities in their showing exercises [27]. Different imperatives incorporate the customary mentality of the school heads, the deficiency of ICT offices, the absence of satisfactory upkeep of the accessible/existing ICT assets, reliance for monetary speculation on the focal government, and reliance on ICT specialist co-ops for programming/courseware [27]. Despite different preparing programs having been given to educators, there is as yet a need to leave on an exhaustive and supported in-administration and preparation for instructors. Similarly, a deliberate advancement program for training chiefs needs additionally to be executed to change the mentality of directors so they appreciate the estimation of ICT in schooling [28]. Considering the absence of specialized staff for keeping up PCs and PC organizations, just as giving client backing to Internet-related exercises, rent plans as opposed to acquisition ought to be investigated as another option. Another imperative that fundamentally affects the utilization of ICT in homerooms is the accessibility of courseware.

The need for ICT coordination in Philippine instruction persistently drives the training area and the United States Agency for International Development (USAID) to attempt an audit on PC availability in government-funded schools and this was accomplished by past and progressing ICT programs. Among these projects were coming up next: Educator's Camp 2013, Laptop for instructors' project, Computerization Program, Online class, and sources, for example, Uni- 
versity of the Philippines-Open University Online Courses and TESDA online courses free of charge. Innovation Enhanced apparatuses were likewise presented, for example, Text2teach, E-reading material, LCD projector, Smartboard, E-room, and E-library [10].

Data and correspondence innovation was seen as a driver for change, a conductor or channel, a type of current innovation, and an instrument for powerful instructing and learning [29]. The disparate comprehension of ICTs was because of their inescapable presence in the public eye. Public school teachers' ideas of ICTs may hold regarding its utilization either by and by or expertly.

In the Manila Times article named "Learning with the assistance of Technology", mechanical advances had enormously changed the schooling scene in that instructing is not, at this point kept to the conventional vis-à-vis conveyance of exercises [30]. The Philippines ought not to be abandoned with regard to applying instructive innovation. The moral and dependable utilization of PCs, tablets, cellphones, and different gadgets can significantly upgrade the learning capacity of understudies, for it has appeared through investigations that kids (and grown-ups besides) can more readily get a handle on and comprehend their exercises in a more loosened up climate, without the prying (and at times deriding) eyes of cohorts or educators.

Innovation keeps on changing our general surroundings. The scholarly world is no exemption. Watchman and Graham's investigation expressed that a few instructors perceive the advantages of coordinating innovation into their study halls, which incorporates the benefits over customary educating and extra freedoms for improving understudy learning [31]. Understudies and instructors wherever are finding energizing and imaginative approaches to make learning more powerful, longer-enduring, and more relevant to the world outside the classroom [6].

\section{Methodology}

A correlation study was employed among the 62 faculty teaching science-related courses of Quirino State University, Philippines. Purposive sampling was used since the population of science instructors in the university is too small and warrants the inclusion of all of them in the study. The researchers have a total sample of 54 and used the Raosoft application with a 5\% of margin of error and $95 \%$ of confidence to determine the number of samples.

The main instrument used was a self-made survey questionnaire. A selfadministered questionnaire is a structured form that consists of a series of closed-ended and open-ended questions [32]. It's called self-administered since responders fill it out without the assistance of an interviewer. Closed-ended questions feature a list of possibilities from which the respondent must choose; these options can be pre-coded. Open-ended questions allow the respondent to give any response they think is suitable, and they should be reported in their own words. It undergoes validation from the experts in the field of ICT, re- 
search, and measuring outcomes, and was pilot tested by some experts in the field of science. The self-made instructor questionnaire consists of the following parts: 1) The profile of the respondents based on age, gender, and the number of years in teaching science subject; 2) Common interactive technology tools used by the science instructors and their level of usage of the said tools; 3) Barriers that respondents encountered in using the identified interactive technology learning tools in teaching science. The barriers are grouped into three parts: the first part consists of five statements that dealt with technical aspects as a barrier, the second part consist of three statements that dealt on lack of training and support as a barrier, and the last part consist of four statements that dealt on views towards ICT usage as a barrier.

The data gathered that were obtained from the survey questionnaire were carefully tallied, summarized, and presented in tabular form. The profile data of the respondents were computed using JASP software version 11.1. Frequency counts and percent distribution were used to gather the profile variables of the respondents. Weighted means were employed to describe the respondents' level of usage of the interactive technology learning tools and barriers in using them. In this study, T-test was used to determine the significant relationship between respondents' level of usage of interactive technology learning tools when grouped according to gender, while one-way Analysis of Variance (ANOVA) was used to determine the significant relationship between respondents' level of usage of interactive technology learning tools when grouped according to age and the number of years in teaching science courses. The test is done to compare between two or more means which helps the researchers to draw various results and predictions about two or more sets of data. Spearman Rho correlation was used to determine the significant relationship between respondents' level of usage of interactive learning tools when grouped according to the three identified barriers in using the tools. Spearman's rank coefficient of correlation is a nonparametric measure of rank correlation (statistical dependence of ranking between two variables).

\section{Results and Discussions}

\section{Profile of the respondents}

Most of the respondents fall mostly in the age range of 30 - 39 years old, with a significant number of 20 or $37 \%$. Sixteen (16) or $30 \%$ belong to the age range of 40 - 49 years old (Table 1). Thirteen (13) or $24 \%$ of the respondents belong to the below 30 years old age bracket. Only five (5) or $9 \%$ belong to the age range of 50 years old and above. The result implies that most of the science instructors were within the age range of 30-39 years old, the right age wherein most of them were already exposed to the different use of latest technologies in teaching and also neither too young nor too old to adapt to the needs of the millennial or the so-called digital learners.

The majority of the respondents (43 or $80 \%$ ) were female and only (11 or 
Table 1. Profile of the respondents.

\begin{tabular}{|c|c|c|c|c|c|}
\hline$A G E$ & $\mathrm{~F}$ & $\%$ & Years of Service & $\mathrm{F}$ & $\%$ \\
\hline Below 30 years old & 13 & 24 & Less than 1 year & 3 & 6 \\
\hline $30-39$ years old & 20 & 37 & $1-5$ years & 16 & 30 \\
\hline 40 - 49 years old & 16 & 30 & $6-10$ years & 9 & 17 \\
\hline Above years old 50 & 5 & 9 & $11-20$ years & 16 & 30 \\
\hline Total & 54 & 100 & 21 - 30 years & 9 & 17 \\
\hline$S E X$ & $\mathbf{F}$ & $\%$ & 30 years above & 1 & 2 \\
\hline Male & 11 & 20 & Total & 54 & 100 \\
\hline Female & 43 & 80 & & & \\
\hline Total & 54 & 100 & & & \\
\hline
\end{tabular}

20\%) were male. This proportion was expected since the teaching profession attracts more female than male teachers.

Sixteen or $30 \%$ of the respondents were both teaching Science for about 1-5 years and $11-20$ years, 9 or $17 \%$ were both about $6-10$ years in teaching and 21 - 30 years respectively. Three (3) or $6 \%$ of them were new teachers who have been in the profession for less than one year and 1 or $2 \%$ of the respondents have been teaching for more than 30 years. The data revealed that most of the respondents have been teaching for about $1-5$ years and $11-20$ years respectively, which means that most of the respondents were not newly hired instructors and most of them already attended different or series of training on the latest trends in teaching science. The data shows that the respondents regardless of years of service are equipped of skills to teach science.

2. Common interactive technology learning tools used by the respondents in teaching science

Table 2 presents the common interactive technology learning tools used by the respondents in teaching science-related courses. The data revealed that most of the respondents were familiar and already using interactive technology learning tools for instruction. It means that when they were hired, the teachers were already equipped with skills and tactics, which is a benefit to them. It has anything to do with the years of service outcomes in Table 1. These interactive learning tools were taught during the revision of their board exam, as well as through other trainings and seminars, according to the respondents' interviews. As to digital gaming, most of the respondents used Kahoot, Quizziz, and OER. The use of digital gaming for instruction is held to support the development of students' cognitive, motivational, emotional, and social outlooks [33]. As to the use of presentation software, respondents were taking an advanced step from using the usual tools to more advance like the usual Powerpoint presentation to a new way of presenting data through Prezi and also upgrade their skills in uploading their lessons and was also careful in choosing and downloading appropriate instructional materials through Slide Share. Respondents are aware of 
Table 2. Common interactive technology learning tools used by the respondents in teaching Science.

\begin{tabular}{|c|c|c|c|}
\hline \multicolumn{2}{|c|}{ Common Interactive Technology Learning Tools } & \multirow{2}{*}{$\begin{array}{c}\text { Frequency } \\
24\end{array}$} & \multirow{2}{*}{$\begin{array}{l}\% \\
44\end{array}$} \\
\hline Digital Gaming & Kahoot & & \\
\hline & Quiziz & 21 & 39 \\
\hline & OER & 3 & \\
\hline \multirow[t]{2}{*}{ Presentation Softwares } & Prezi & 31 & 49 \\
\hline & Slide share & 32 & 51 \\
\hline \multirow[t]{2}{*}{ Simulations } & Phet & 36 & 67 \\
\hline & Physics lab & 1 & 2 \\
\hline Blogging & Padlet & 10 & 19 \\
\hline \multirow[t]{2}{*}{ Video Recording } & Screencast-o-matic & 12 & 22 \\
\hline & Youtube & 7 & 13 \\
\hline \multirow[t]{2}{*}{ Social Networking } & Facebook & 37 & 69 \\
\hline & Instagram & 5 & 9 \\
\hline \multirow[t]{2}{*}{ Others } & Google drive & 24 & 44 \\
\hline & Plickers & 1 & 2 \\
\hline
\end{tabular}

blogging using Padlet where they can post their views, comments, photos, and videos about the lessons discussed and present their outputs on their learning tasks. With regards to social networking, respondents are using more of social media in their everyday lives which include learning and enriching concepts learned in classrooms. Facebook and Instagram allow the users to do it all: post a profile, photos, videos, chat, blog, and connect with their peers through individual bulletin boards, private groups, and forums. Aside from the mentioned interactive technology learning tools used by the respondents, some are continuously exploring and learning the latest technology tools in their teaching and learning as shown on their use of google drive and plickers.

\section{Respondents' level of usage of interactive technology learning tools in} teaching science

As presented in Table 3, SlideShare as a technology learning tool was used "often" or once a week by the respondents with a mean value equal to 3.43. Seven out of 15 tools were used "sometimes" or once a month with the following mean values: 3.14 (Youtube), 3.2 (Instagram), 3.02 (Google Drive), 3 (OER, Physics Lab, e-sim and Plickers), Four out 15 tools were used "seldom" or twice a year with the following mean values: 2.54 (Facebook), 2.38 (pHet), 2.09 (Prezi) and 1.92 (Kahoot). Three out of 15 tools got an average mean range from 1.80 1.00 which means never or no record of usage by most of the respondents, the following tools were (Quiziz) with a mean value of 1.77, Padlet and Screencast-o-Matic with a mean value of 1.33 respectively. The data revealed that most 
Table 3. Level of usage of interactive technology learning tools used by the respondents in teaching Science.

\begin{tabular}{ccccccc}
\hline $\begin{array}{c}\text { Interactive Technology } \\
\text { Learning Tools }\end{array}$ & N & Missing & Mean & SD & QD & Rank \\
\hline Prezi_20 & 53 & 1 & 2.09 & 1.11 & SE & 11 \\
Slide share_21 & 53 & 1 & 3.43 & 1.39 & O & 1 \\
Padlet_22 & 53 & 1 & 1.32 & 0.7 & N & 14.5 \\
Screencast-o-matic_23 & 52 & 2 & 1.33 & 0.71 & N & 14.5 \\
You-tube_24 & 7 & 47 & 3.14 & 1.86 & SO & 3 \\
Facebook_25 & 39 & 15 & 2.54 & 1.12 & SE & 9 \\
Kahoot & 52 & 2 & 1.92 & 1.1 & SE & 12 \\
Phet simulations & 53 & 1 & 2.38 & 1.23 & SE & 10 \\
Physics lab & 1 & 53 & 3 & - & SO & 6.5 \\
Quizziz_29 & 52 & 2 & 1.77 & 1.15 & N & 13 \\
Google drive_30 & 54 & 0 & 3.02 & 1.47 & SO & 4 \\
e-sim & 1 & 53 & 3 & - & SO & 6.5 \\
OER_32 & 3 & 51 & 3 & 1 & SO & 6.5 \\
Plickers & 3 & 51 & 3 & 1 & SO & 6.5 \\
\hline
\end{tabular}

Legend: 1.00 - 1.80 Never (N); 1.81 - 2.60 Seldom (SE); 2.61 - 3.40 Sometimes (SO); 3.41 - 4.20 Often (O); 4.21 - 5.00 Always (A).

of the common interactive tools known to most of the respondents include Slideshare, Youtube, Instagram, and Google Drive and other tools were only used by few respondents and therefore in general was unknown to most of the respondents. These tools include Quiziz, Padlet, and Screencast-o-Matic. The data also shows that learners nowadays are continuously engaging themselves in the use of technology not only in schools but also in their day-to-day activities.

\section{Significant difference between respondents' level of usage of interactive} technology learning tools and the profile variables

Table 4 presents the significant difference between the respondents' level of usage of interactive technology learning tools when grouped according to age, gender, and the number of years teaching science courses.

1) Age. The study proved that respondents' levels of usage significantly vary when grouped according to age. Since most of the respondents were $30-49$ years old, few respondents who are below 30 years old, and 50 and above years old reflect a significant increase or decrease in their level of usage of the interactive learning tools mentioned.

2) Gender. The study shows that there is no significant difference between the respondents' levels of usage when grouped according to gender. This implies that gender does not affect the level of usage of interactive learning tools.

3) Number of years teaching science courses. The study shows that there is a significant difference in the respondents' level of usage when grouped according 
Table 4. Significant difference between the respondents' level of usage of interactive technology learning tools when grouped according to profile.

\begin{tabular}{cccccccc}
\hline $\begin{array}{c}\text { Profile of the } \\
\text { Respondents }\end{array}$ & N & M & SD & df & F & p-value & Remarks \\
\hline Age & 54 & 1.99 & 0.9597 & 12 & 2.441864 & $0.01865^{*}$ & Significant \\
Gender & 54 & 2 & 0.8786 & T-test $=-1.28$ & 2.306 & $\begin{array}{c}\text { Not } \\
\text { Significant }\end{array}$ \\
$\begin{array}{c}\text { Number of years } \\
\text { teaching science } \\
\text { courses }\end{array}$ & 54 & 1.71 & 1.0796 & 12 & 2.922691 & $0.002759^{\star}$ & Significant \\
\hline
\end{tabular}

${ }^{*} \mathrm{p}<0.05$.

to the number of years teaching science courses. This implies that the length of time spent in teaching the subject reflects a significant change in the degree of usage of interactive learning tools.

5. Barriers encountered by the respondents in using interactive technology learning tools in science instruction

Table 5 below shows the barriers encountered by the respondents in using interactive technology learning tools summarized into 12 statements and categorized into three aspects namely technical, lack of training and support, and negative attitudes towards ICT usage, and also presented were the mean, verbal interpretation, and rank for each barrier. Mean results range from 1.907 to 4.019 which were verbally interpreted as "slightly serious to serious" barriers encountered by the respondents.

Slow internet connectivity of computers used by the students ranked as number 1 as the main barrier under the Technical aspects with $4.02 \mathrm{WM}$ and verbally interpreted as "Serious" problem. It shows that this problem is not under the control of the teachers. It implied that the teachers should fully understand this problem for them to adjust and change their strategies according to the technological needs to the students.

Under the lack of training and support barrier, Lack of knowledge on enhanced technology learning tools used in science instruction was ranked number 1 with weighted mean of 3.11 and verbally interpreted as "Moderately Serious". It meant that, despite the fact that the teachers were recently appointed, they still needed to undergo some training relating to the subjects they were teaching, particularly in Science, where there are many new developments and technology taking place these days.

For the Negative Attitudes towards ICT Usage barrier, too difficult for teachers to integrate Enhanced Technology Learning Tools in the curriculum came up as the top barrier with weighted mean of 2.59 and verbally interpreted as "Slightly Serious" problem. It demonstrates that teachers' expertise on how to integrate enhanced technological learning tools into the curriculum is still weak. It is clear that the mapping of subject outcomes in this subject should be closely checked in order to ensure that the teachers' competency matches the desired 
Table 5. Barriers encountered by the respondents in using interactive technology learning tools in science instruction.

\begin{tabular}{|c|c|c|c|c|c|}
\hline Barriers Encountered & $\mathbf{N}$ & Mean & SD & Description & Rank \\
\hline Technical Aspects & 54 & 3.419 & 1.018 & $S$ & 1 \\
\hline 1. Insufficient number of computers to be used in teaching & 54 & 3.389 & 1.472 & MS & 3 \\
\hline 2. Insufficient number of computers with internet connectivity & 54 & 3.907 & 1.103 & S & 2 \\
\hline 3. Slow internet connectivity of computers used by the students & 54 & 4.019 & 0.961 & S & 1 \\
\hline 4. Insufficient number of laptops/netbooks for teachers & 54 & 2.833 & 1.551 & MS & 5 \\
\hline 5. Computers are out of date and/or needing repairs & 54 & 2.944 & 1.25 & MS & 4 \\
\hline Lack of Training and Support & 54 & 2.939 & 0.999 & MS & 2 \\
\hline $\begin{array}{l}\text { 1.Lack of knowledge on enhanced technology learning tools used in science } \\
\text { instruction }\end{array}$ & 54 & 3.111 & 1.127 & MS & 1 \\
\hline 2. Insufficient technical support for science teachers & 54 & 2.981 & 1.09 & MS & 2 \\
\hline 3. Lack of ICT skills for science teachers & 54 & 2.722 & 1.156 & MS & 3 \\
\hline Negative Attitudes towards ICT Usage & 54 & 2.231 & 0.972 & SS & 3 \\
\hline $\begin{array}{l}\text { 1. Too difficult for teachers to integrate Enhanced Technology Learning Tools } \\
\text { in the curriculum }\end{array}$ & 54 & 2.593 & 1.108 & SS & 1 \\
\hline $\begin{array}{l}\text { 2. Colleagues negative views about ICT hinders me to use Enhanced Technology } \\
\text { Learning Tools in my science class }\end{array}$ & 54 & 1.907 & 1.033 & SS & 4 \\
\hline $\begin{array}{l}\text { 3. Lack of support of school administration in the use of ICT in teaching } \\
\text { and learning science. }\end{array}$ & 54 & 2.111 & 1.284 & SS & 3 \\
\hline $\begin{array}{l}\text { 4. Lack of monitoring and evaluation of the division personnel on ICT integration } \\
\text { in the school curriculum }\end{array}$ & 54 & 2.315 & 1.357 & SS & 2 \\
\hline
\end{tabular}

Legend: 1.00 - 1.80 Not a Barrier (NB); 1.81 - 2.60 Slightly Serious (SS); 2.62 - 3.40 Moderately Serious (MS); 3.42 - 4.20 Serious (S); 4.21 - 5.00 Very Serious (VS).

subject results. It is critical in the school's part because they must undertake this observation in order to preserve the quality of their educational services.

To summarize the barriers encountered by the respondents, Technical Aspects came out to be the top barrier in using interactive technology learning tools in science instruction (WM $=3.42$ and verbally interpreted as "Serious"). It was followed by lack of training support with weighted mean of 2.40 and verbally interpreted as "Moderately Serious" and came last in rank was the Negative Attitudes towards ICT Usage (WM $=2.23$ and Verbally interpreted as "Slightly Serious").

With the data above, it is clear that the school administration must provide technical assistance to instructors in order to develop their abilities. According to the responses, they are committed to their job and wish to develop their teaching abilities with the assistance and support of the school administration.

6. Significant relationship between respondents' level of usage of interactive technology learning tool when grouped according to barriers such as technical aspects, lack of training and support, and views on ICT usage.

The study reveals that there is no significant relationship between respondents' level of usage of interactive technology learning tools when grouped according to barriers such as technical aspects, lack of training and support, and 
views on ICT usage (Table 6). This implies that the level of usage is not affected by the presence or absence of these barriers.

7. ICT development plan may be proposed to increase science instructors' level of performance in the use of interactive technology learning tools in science instruction

The proposed ICT development plan strategies to be implemented were based on the findings of the study and aims to improve skills and knowledge in using interactive technology learning tools in teaching among science instructors of the university. It focuses on technical aspects specifically on the insufficient number of computers and slow internet connectivity. At the end of the period, there should be an increasing number of computers with upgraded internet connectivity. Furthermore, the ICT development plan also considers the lack of training and support to the instructors thereby instructors should be sent to training to update their knowledge and enhance their skill on the use of interactive technology learning tools.

\section{Conclusions and Recommendations}

Based on the findings derived from this study, the following conclusions were drawn.

The highest percent of the respondents is from the age bracket of 30-39 years old. Female instructor-respondents outnumbered male instructor-respondents. The highest percentage of respondents' teaching experience ranges from 1-5 years and $11-20$ years respectively.

The common interactive technology learning tools used by the respondents were the following: Facebook, Phet Simulation, Slide Share, Prezi, and Kahoot.

The level of usage of the interactive technology learning tools of the respondents was the following: Often-Slide Share, sometimes-Instagram, Youtube, Google Drive, Plickers, e-sim and Physic Lab; seldom-Facebook, Phet, Prezi and Kahoot; and the last three tools based on the findings were never been used by most of the respondents Quiziz, Padlet, and OER.

There is a significant difference between the respondents' level of usage of interactive technology learning tools when grouped according to age and the number of years in teaching Science courses, while there is no significant difference when grouped according to gender. It can be concluded that the level of

Table 6. Significant relationship between respondents' level of usage of interactive technology learning tool and barriers in using the tool.

\begin{tabular}{cccccc}
\hline & \multicolumn{5}{c}{ Spearman Rho } \\
\hline $\begin{array}{c}\text { Barriers in Using Interactive } \\
\text { Technology Learning Tools }\end{array}$ & $\mathbf{r}$ & p-value & Degree of Association & Remarks \\
\hline Technical Aspects & -13584 & 2 & weak/no correlation & Not Significant \\
Lack of Training and Support & -1.54414 & 2 & weak/no correlation & Not Significant \\
Views Toward ICT & -1.258 & 2 & weak/no correlation & Not Significant \\
\hline${ }^{*} \mathrm{p}<0.05$. & & & &
\end{tabular}


usage of the respondents varies on their age level and the number of years in teaching the course but not on gender.

The barriers encountered by the respondents in using interactive technology learning tools in science instruction based on the degree of seriousness were the following: Serious problems-"Slow internet connectivity of computers used by the students", "Insufficient number of computers with internet connectivity", and "Insufficient number of computers to be used in teaching". A moderately serious problem encountered by the respondents in using interactive technology learning tools were the following: "Lack of knowledge on interactive technology learning tools used in Science instruction", "Insufficient technical support for science teachers", "Computers are out of date and/or needing repairs", and "The insufficient number of laptops/netbooks for teachers". The last four barriers were considered by the respondents as slightly serious problems they encountered in using interactive technology learning tools: "Too difficult for teachers to integrate interactive technology learning tools in the curriculum", "Lack of monitoring and evaluation of the division personnel on ICT integration in the school curriculum", "Lack of support of school administration in the use of ICT in teaching and learning science", and "Colleagues negative views about ICT hinders me to use interactive technology learning tools in my science class". Based on rank for the three categories of identified barriers in using interactive technology learning tools, the top barriers fall under technical aspects followed by lack of training and support of science instructor and lastly considered as a slightly serious problem is on views towards ICT usage.

There is no significant relationship between the respondents' level of usage of interactive technology learning tools when grouped according to technical aspects, lack of training and support, and views towards ICT usage as barriers. It can be concluded that since the mean level of usage of the respondents in using the tools is only categorized as sometimes, therefore, technical aspect as a barrier, lack of training and support, and views towards ICT usage was not considered as a very serious problem thus shows negligible correlation.

The researchers proposed the following ICT development plan with partnership and collaboration with internal and external stakeholders through adopt-aschool program for additional computer packages with faster internet connectivity in the university, training, and seminars on the use of interactive technology learning tools for instruction, mentoring, and coaching session on ICT usage, LAC sessions on existing problems encountered in using the tools, and conducting a search for best ICT tools implementer.

With the foregoing conclusions, the following recommendations are hereby endorsed:

1) Access. Special consideration should be given to ICT connectivity and accessibility for educational purposes. Every public secondary school should be provided with fast connectivity and accessibility to ensure effective usage of interactive technology learning tools among Science teachers. 
2) Science instructors. It is necessary to focus on training Science teachers in the use of interactive technology tools and challenge them to develop their teaching support materials with the aid of the said tools. Science teachers should work together to establish networks that support them in their transition to ICT-based education. They should also be open to online knowledge-sharing networks to improve their ICT integration in the classroom setting. Although this will require a big budget, it is nevertheless essential to guarantee equal access and overcome the digital divide.

3) Cost. Any initiative, be it from the government, internal or external stakeholders, should make lobbying for investments in computers a priority. The insufficient number of computers with fast internet connectivity is one of the main barriers to the effective use of interactive technology tools in teaching especially to those schools located in far-flung barangays.

4) Government and Policy Implementers. A sustainable partnership between the government, private sectors, and civil society must be created to offset and mitigate the complexities of using interactive technology learning tools in public secondary schools. Due to the high cost of the latest computer facilities, looking for donors must be strategic and requires careful planning, such as innovative ways of looking for sponsors and creating strong linkages among other agencies.

5) Monitoring and Evaluation. Science instructors working on effective usage of interactive technology learning tools at all levels must closely monitor the progress of their teaching to ensure that they progress effectively. To include the 1) Conduct LAC sessions to share best practices and share possible problems and difficulties that might be encountered in using the tools; 2) Organize faculty ICT Development Program regularly to share new knowledge and skills in using latest tools in teaching; 3) Every classroom should have at least one computer with internet and an LCD projector.

6) Future research could incorporate other characteristics in the study, such as other respondents who taught different courses, other respondents such as the department chair and deans to gain a different perspective, and other variables such as trainings attended, work experience, and so on.

\section{Conflicts of Interests}

The authors declare no conflict of interest regarding the publication of this paper.

\section{References}

[1] Briones, L. (2018) DepEd Chief: Teachers Still at the Forefront in 21st Learning.

[2] Eicketman, B.A. (2017) Teachers' Attitudes and Beliefs Regarding ICT in Teaching and Learning in European Countries. European Educational Research Journal, 16, 36-50. https://doi.org/10.1177/1474904117725899

[3] Majaski, C. (2020, October 24) Hypothesis Testing. https://www.investopedia.com/terms/h/hypothesistesting.asp

[4] Jukes, I. (2019, August 12) Famous Quotes about Technology in Education. Astro- 
reality Stories.

[5] Kassebaum, N. (2016) The SAMR Model Part Two.

[6] Almara'beh, H.A.E. (2015) The Role of ICT in Teaching Science Education in Schools. International Journal of Advances Research in Computer in Computer Science and Software Engineering, 5, 761-764.

[7] De Jesus, F.S. and De Jesus, M.B. (2021) Spending Habits of Public School Teachers in Palayan City. Open Access Library Journal, 8, e6332. https://doi.org/10.4236/oalib.1106332

[8] Bonifacio, L.M. (2013) Developing Information Communication Technologies (ICT) Curriculum Standards for K-12 Schools in the Philippines. Doctoral Dissertation, University of the Philippines, Quezon City.

[9] Himmelsbach, V. (2020, March 12) 20 Pros \& Cons of Technology in the Classroom in 2021 [+ Free Tech Tips from Profs]. https://tophat.com/blog/technology-in-the-classroom-pros-and-cons/

[10] Salihi, A. (2015) The Use of ICT in Science Education. Global Educational Research Journal, 3, 258-260.

[11] Woodlift, Z. (2015) The Effective Use of Video in Higher Education. Evolution of Educational Technology, 65-69.

https://www.inholland.nl/media/10230/the-effective-use-of-video-in-higher-educati on-woolfitt-october-2015.pdf

[12] Jewitt, C.F. (2018, May 5). http://www.gov.scot/Publications

[13] Chauhan, A. (2020, March 22) 11 Digital Education Tools for Teachers and Students. https://elearningindustry.com/digital-education-tools-teachers-students

[14] Nagel, D. (2019, October 25) How Teachers Use Technology in the Classroom. Journal.com.

https://thejournal.com/articles/2019/05/08/how-teachers-use-technology-in-the-cla ssroom.aspx

[15] McNeely, B. (2020, February 18) Using Technology as a Learning Tool, Not Just the Cool New Thing. Educause.edu.

https://www.educause.edu/research-and-publications/books/educating-net-generati on/using-technology-learning-tool-not-just-cool-new-thing

[16] O’Donnelly, C.O. (2018, April 22) TEL Tools-Pedagogical Resources for Technology Enhanced Teaching and Learning.

https://www.teachingandlearning.ie/tel-tools-pedagogical-resources-for-technology -enhanced-teaching-and-learning

[17] Sharma, R.M. (2017) Using ICT in Secondary School Science Teaching-What Students and Teachers in Trinidad and Tabago Say? European Journal of Education Studies, 3, 197-211.

[18] Hyndman, B. (2020, March 14) Ten Reasons for Teachers Can Struggle to Use Technology in the Classroom.

https://theconversation.com/ten-reasons-teachers-can-struggle-to-use-technology-i n-the-classroom-101114

[19] Ihechukwu, N.N. (2016) Impediments to Integration of ICT in Teaching and Learning of Mathematics in Secondary Schools. International Journal of Advanced Academic Research, 2, 5-13.

[20] Demirbag, M.K. (2018) Preservice Teachers' Risk Perception and Willingness to Use Educational Technologies: A Belief System Approach. Journal of Education and Future, 14, 15-31. https://doi.org/10.30786/jef.379741

[21] Yemothy, N. E. (2020, March 10) Improving Educational Technology Integration in 
the Classroom.

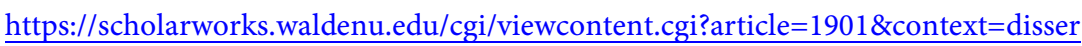
tations

[22] Wang, T. (2017) Overcoming Barriers to "Flip": Building Teachers' Capacity for Adoption of Flipped Classroom in Hongkong Secondary School. Research and Practice in Technology Enhanced Learning, 12, 1-11.

https://doi.org/10.1186/s41039-017-0047-7

[23] Network, F.L. (2019) Flipped Classrooms. https://files.eric.ed.gov/fulltext/EJ1095734.pdf

[24] Prasad, V.L. (2015) Barriers to ICT Use Information and Communication Technology (ICT) in Secondary Schools: Teachers' Perspective. Journal of Management Research, 7, 190-208. https://doi.org/10.5296/jmr.v7i2.6935

[25] Van Melle, E. (2019, October 28) Conditions That Facilitate the Successful Implementation of ICT.

[26] Padmavathi, M. (2020, March 25) An Overview of Barriers in Technology Integration in Schools and Their Interrelationship. https://www.researchgate.net/publication/314398633

[27] Dotong, C.D. (2016) Barriers for the Educational Technology Integration in Contemporary Classroom Environment. Asia Pacific Journal of Education, Arts and Sciences, 3, 1-13.

[28] Wallet, P. (2018) ICT in Education in Asia a Comparative Analysis of ICT Integration and e-Readiness in Schools across Asia. Information Paper No. 22, UNESCO Institute for Statistics, Montreal.

[29] Lachica, L. (2015) Classroom Communication and ICT Integration: Public High School Notions. International Journal on Integrating Technology in Education, 4, 1-14. https://doi.org/10.5121/ijite.2015.4201

[30] Espinosa, J. (2018, May 2) Learning with the Help of Technology. http://www.manilatimes.net/learning-with-the-help-of-technology/286384

[31] Hartman, R.T. (2019) Educators' Perception of Technology Integration into the Classroom: A Descriptive Case Study. Journal of Research in Innovative Teaching and Learning, 3, 236-249. https://doi.org/10.1108/JRIT-03-2019-0044

[32] Health Systems Assessment and Planning Manual: Self-Administered Questionnaire.

https://www.wits.ac.za/media/migration/files/cs-38933-fix/migrated-pdf/pdfs-3/hsa \%20-\%20section\%202.pdf

[33] Licorish, S.O. (2020, March 14) Students' Perception on Kahoot's Influence on Teaching and Learning.

https://telrp.springeropen.com/articles/10.1186/s41039-018-0078-8 